\title{
ANNIE GET YOUR GUN 'CAUSE HELP AIN'T COMIN': THE NEED FOR CONSTITUTIONAL PROTECTION FROM PEER ABUSE IN PUBLIC SCHOOLS
}

\author{
ADAM MICHAEL GREENFIELD $\dagger$
}

\section{INTRODUCTION}

"Stay in school" and "stay out of trouble"-these instructions to children have been a fixture of American society almost as long as the school system itself. Public schools have long been considered sanctuaries where mind and body could be developed to their fullest potential. Indeed, so deeply held are society's convictions on the virtues of public education that all states have enacted legislation inandating attendance up to a certain age. ${ }^{1}$

Although the perception of the schoolhouse as a safe haven persists, the reality of what goes on inside its walls is somewhat different. All too often, the school seems to subject its students to the very evils from which it was thought to have shielded them. Because "[t]he school has always served as a social barometer, a insights.

$\dagger$ I would like to thank Professor Thomas Rowe for his invaluable assistance and

1. By 1918, all 48 states had compulsory education or school attendance laws. LAWRENCE A. CREMIN, AMERICAN EdUCATION: THE Metropolitan EXPERIENCE, 1876-1980, at 297 (1988). To avoid the racial integration of public schools mandated by Brown v. Board of Educ., 347 U.S. 483 (1954), some states later repealed their compulsory education laws. During the next decade, however, all these states, with the exception of Mississippi, reenacted their statutes. LAWRENCE Kotin \& William E. AikMAN, LEGAL FOUNDATIONS OF COMPULSORY SCHOOL ATTENDANCE 34 (1980). Mississippi ultimately followed suit in 1987 with a new compulsory school attendance law. See Miss. CODE. ANN. \& 37-13-91 (1990).

Compulsory schooling laws typically require children to attend school from age seven to age fifteen, but the requirements vary among states. See, e.g., CAL. Educ. CODE \& 48200 (West 1993) (ages six to eighteen); MNN. STAT. ANN. \& 120.101 (West 1993) (ages seven to sixteen); N.Y. EDUC. LAW $\$ 3205$ (McKinney 1981) (ages six to sixteen); PA. STAT. ANN. tit. 24, \& 13-1326 to -1327 (1992) (ages eight to seventeen). 
reflection of national historical trends," it too has fallen victim to the spiraling violence of American society. Education's reign as the "the great equalizer" is giving way to its new status as "the great leveller."

Particularly disquieting is the increasing regularity of injuries that students suffer at the hands of their peers. This long-standing problem has evidenced itself in many forms, including physical and verbal abuse, sexual assaults and harassment, stabbings, shootings, and attacks on mentally handicapped students. In a recent USA Today poll of children in grades six through twelve, more than one-third said they felt unsafe at school, up from almost one-quarter in 1989. About one half of those surveyed said they knew someone who brought a weapon to school, and $50 \%$ also said they knew someone who had switched schools to feel safer. More specifically, $43 \%$ said they avoid bathrooms, and $27 \%$ of girls said they were sexually harassed last year. A full $63 \%$ said they would learn more if they felt safer. ${ }^{3}$ Such statistics illustrate that many of today's schoolchildren are becoming casualties of an educational system plagued by violence. ${ }^{4}$

2. American Heritage Dictionary 108 (1969) (quoting Paul P. Molk).

3. See Leslie Ansley, Many Teens Feel Unsafe in School, USA TODAY, Aug. 13, 1993, at $1 \mathrm{~A}$.

4. See, e.g., Robert A. Frahm \& Theresa S. Barger, Four of Five Teens Sexually Harassed in School, Survey Says, HARTFORD COURANT, June 2, 1993, at A1 (according to one survey, four out of five public school children in grades eight to eleven, including boys, reported some form of sexual harassinent); Rob Hotakainen, Schools Quizzed on Sexual Harassment, STAR TRIB., April 30, 1993, at 1B (noting that 1110 incidents of sexual harassinent and another 95 incidents of sexual violence were reported in Minnesota schools last year); Rena Pederson, Young Girls Targeted as Sex Objects, SAN DIEgo UNION-TRIB., March 31, 1993, at B7, (noting recent national survey that reported girls ages nine to nineteen being subjected to pinching, grabbing, obscene remarks, and even rape by male classmates); Creating Alternatives to Classroom Violence, PR NEwswIRE, July 21, 1993, available in LEXIS, Nexis Library, PRNEWS File (reporting that the National Education Association estimates that as many as 100,000 students carry guns to class each day); Sonya Live (CNN television broadcast, July 20, 1993) (transcript available in LEXIS, Nexis Library, CNN File) (stating that according to the Joyce Foundation, $59 \%$ of sixth- to twelfth-graders could get a handgun if they wanted one; $22 \%$ carried a weapon to school this year; and $39 \%$ know someone killed or injured by gunfire). But see Nightline: Sexual Harassment in Schools (ABC television broadcast, June 18, 1993) (transcript available in LEXIS, Nexis Library, ABCNEW File) (reporting that some experts doubt the accuracy of students' testimonies and question the broad definition of "sexual harassment" used in some polls).

The problem of violence in schools is not limited by geographic boundaries. See, e.g., Mike Lamb, Block Watch Adapted for Schools, CALGARY Herald, May 19, 1993, at B3 ("The notion that schools are an absolutely safe environment has been crushed in the 
Behind the numbers are the individual student victims and their daily sufferings. One sixteen year old from Houston remarked, "You shouldn't have to worry that someone's waiting to kill you." Another student from Washington contended, "The constant threat is 'chipping away at our schools' effectiveness . . . . It drains the energy of the students every day." school police officer confirmed that there is an epideumic of violence: "The few bad kids are the focus of all the other kids' fears and worries .... And they have a legitimate concern about violence inside school because soine of the people they go to class witl are urban terrorists." The implication is clear: "There are criminals on campus. And one lall monitor, two lunch-room supervisors, and a half-time counselor don't pose inucl of a deterrent." ${ }^{\text {8 }}$

An alarming, but not unusual, example of this type of student-agamst-student abuse is found in D.R. v. Middle Bucks Area Vocational Technical School. ${ }^{9}$ In Middle Bucks, two female vocational school students alleged that several male students im their graphic arts class liad pliysically, verbally, and sexually abused them over the course of several inonths. ${ }^{10}$ They claimed that several times a week they were forcibly carried into the classroom's darkrooln or unisex bathroom and pliysically and sexually assaulted. The alleged abuse consisted of offensive touching of their

past few years.") (quoting Sgt. Lanny Fritz of the Calgary police force); Britain Confronts Classroom Violence After Teacher Battered, REUTERs, Marcl 25, 1993, available in LEXIS, Nexis Library, WIRES File (expressing concern about classrooin violence in response to 16,000 attacks on teacliers in the past 12 months and several high-profile murders).

5. Ansley, supra note 3, at $1 \mathrm{~A}$.

6. Linda P. Campbell, Teens Appeal to Officials: Help Curb Violence, CHI. TRIB., July 16, 1993, at 2 .

7. Mike Barnicle, The Curriculum Covers Violence, Boston Globe, May 13, 1993, at 25 .

8. Dan McGrath, School Provides an Education in Violence, SACRAMENTO BEE, May 24, 1993, at A2; see also Elizabeth W. Hall, Schools Unsafe, Charges Father of Beaten Teen, The DurhaM Herald-SUN, October 12, 1993, at A1, A2 ("They were able to walk right into the front door of the scliool, assault someone and leave witlout being seen. It's pretty slocking this can liappen in broad daylight in a sclool. They need some security there. He never knew what hit him.") (quoting the father of a ligh school student beaten unconscious at school by three teenagers).

9. 972 F.2d 1364 (3d Cir. 1992) (en banc), cert. denied, 113 S. Ct. 1045 (1993).

10. One of the students, D.R., was considered an "exceptional student" under state law because of a liearing impairment and related communication problems. Id. at 1366 n.5. 
breasts and genitalia, sodomization, and forced acts of fellatio. They also were forced to watch such acts performed on other students. ${ }^{11}$

Durmg the period in question, the student-teacher in charge of the class experienced considerable difficulty in maintaining control over the students and apparently left the classroom unsupervised. The teaclier did not witness the alleged acts but observed the use of obscene language and gestures as well as the pliysical liarassment of female students. In fact, the teacher lierself was also a victim of this harassment. ${ }^{12}$ Althougl the plaintiffs did not inform the teacher of the repeated acts of sexual abuse, one of them alleged that she did report an attempted sexual assault to the school's assistant director. This official failed to take any steps to remedy the problem. Other school officials and teacliers also allegedly had knowledge of the non-sexual misconduct taking place in the classroom. ${ }^{13}$

The questions arise as to what role the school board played im connection with these mcidents, and, more miportantly, what responsibility it should bear in the aftermatll. Under 42 U.S.C. \& $1983,{ }^{14}$ a federal civil rights enforcement statute, a school board may be subject to liability when it violates the constitutional riglts of its students. In assessing a school's section 1983 liability, mucl will depend on whether it is found to have caused the violence or sexual deviance taking place under its roof. ${ }^{15}$ Establishing school liability under section 1983 is especially problematic when the person inflictmg the harm is a student, rather than a scliool employee. Courts-such as the U.S. Court of Appeals for the Third Circuit in Middle Bucks-have recently confronted the issue of a public sclool's hability for physical and sexual assaults on schoolchildren by fellow students. Most liave decided that because the

11. Id. at 1366.

12. Id.

13. Id.

14. Section 1983 provides,

Every person who, under color of any statute, ordinance, regulation, custom, or usage, of any State .or Territory or the District of Columbia, subjects, or causes to be subjected, any citizen of the United States or other person within the jurisdiction thereof to the deprivation of any rights, privileges, or immunities secured by the Constitution and laws, shall be hable to the party injured in an action at law, suit in equity, or other proper proceeding for redress.

42 U.S.C. § 1983 (1988).

15. See Arroyo v. Pla, 748 F. Supp. 56, 60 (D.P.R. 1990); see also 42 U.S.C. § 1983. 
school does not directly cause peer abuse, there is no state action and thus no constitutional violation. ${ }^{16}$ For such courts, the private nature of the violence proves fatal to students' constitutional claims against public schools for peer abuse.

Part I of this Note discusses the necessity of proving the existence of state action to hold school boards constitutionally liable for peer abuse. To sliow state action, victims of peer abuse must assert that the school had an affirmative constitutional duty to protect them from private harms. Part I discusses the U.S. Supreme Court's landinark decision in DeShaney v. Winnebago County Dept. of Social Services, ${ }^{17}$ which governs states' obligation to protect individuals from private harms. A critique of the state action doctrine follows, focusing on the imprecision with which it measures state responsibility. Part I then applies the principles announced im DeShaney to the school context. Arguing that the public school assumes a constitutional duty to protect its students, it concludes that school attendance is a form of "custody" under both the legal and functional definitions of the terin. Part II of this Note then exannines the requirements for a section 1983 cause of action and how courts have interpreted thein to bar virtually all clainns against a school board.

This Note argues that schools should bear responsibility for incidents of serious peer abuse, even. if they are not the "direct" cause of the harm. Requiring scliool attendance confines students through an assertion of legal authority. Such confinement exposes children to peer abuse and may render them less capable of protecting theinselves froin such abuse. Consequently, students are both legally and functionally in the school's custody and have a constitutional right to be protected. Thus, the private nature of peer abuse should not necessarily preclude public responsibility. Finally, this Note recommends that school boards should be held constitutionally liable for their de facto policies of inaction towards peer abuses.

16. See infra notes 38,57 and accompanying text.

17. 489 U.S. 189 (1989). 


\section{FINDing A FourteEnTH AMENDMENT RIGHT TO PROTECTION}

For victims of abuse in public schools, whether at the liands of a student or a school employee, three areas of redress are potentially available: an action in tort under applicable state law; a sexual discrimination claim under Title IX of the Education Amendments of $1972 ; ;^{18}$ or a claim of substantive due process violation alleged under 42 U.S.C. $\S 1983$. Altliough eacli represents an important source of recovery, it is the section 1983 reinedy that has attracted the most attention. ${ }^{19}$

Section 1983 provides a federal cause of action to those whose constitutional or federal statutory rights have been violated by people acting under color of state law. ${ }^{20}$ The statute creates no substantive rights of its own but provides a vehicle for enforcement of rights already guaranteed by the Constitution or by federal law. ${ }^{21}$ Accordingly, for a section 1983 action to he, a violation

18. 20 U.S.C. $\$ \S 1681-88$ (1988). Title IX provides, in pertinent part, "No person in the United States shall, on the basis of sex, be excluded from participation in, be denied the benefits of, or be subjected to discrimination under any education program or activity receiving Federal financial assistance .... Id. § 1681(a). Title IX defines an educational institution as "any public or private preschool, elementary, or secoudary school, or any institution of vocational, professional, or higher education." Id. § 1681(c).

The U.S. Supreme Court recently ruled that students may recover money damages for violations of Title IX. See Franklin v. Gwinnett County Pub. Sch., 112 S. Ct. 1028, 1038 (1992); see also Monica L. Sherer, Comment, No Longer Just Child's Play: School Liability Under Title IX for Peer Sexual Harassment, 141 U. PA. L. REv. 2119 (1993) (advocating the expansion of Title IX protections to encompass student-to-student sexual harassment).

19. The wisdom of pursuing a state common law, as compared to a federal statutory remedy, often depends on the existence of sovereign immunity. In states in which sovereign immunity has been either limited or abolished, common law tort actions provide an adequate remedy for many of the injuries that plaintiffs in other states would pursue under $\S 1983$. In those states in which broad sovereign immunity is still in effect, however, common law tort actions are not available, creating the need for sone alternative federal avenue of redress.

Section 1983 offers some unique advantages over state tort actious, including a wider range of federal, constitutional, and statutory rights that may be inplicated by school misconduct; a broader range of potential defendants, including not only the actor, but supervisors, board members, and school entities; nore generous federal law danages standards; and the possibility of recovering costs and attorneys' fees for prevailing plamtiffs. William D. Valente, Liability for Teacher's Sexual Misconduct with Students-Closing and Opening Vistas, 74 Educ. L. Rep. (West) 1021, 1022 n.4 (1992).

20. 42 U.S.C. $\$ 1983$. For the relevant text of $\S 1983$, see supra note 14.

21. See Baker v. McCollan, 443 U.S. 137, 144 n.3 (1979); Chapman v. Houston Welfare Rights Org., 441 U.S. 600, 617-18 (1979) (quoting CONG. GLOBE, 42d Cong., 1st Sess. 568 (1871) (statement of Senator Edmonds)); Wideman v. Shallowford Community 
of an underlying federal right must first be established and be shown to have taken place "under color of [state] law."22 In the context of peer-on-peer abuse, the plaintiff alleges that the school board's action (or inaction) caused a deprivation of his Fourteenth Amendment substantive due process rights. In a 1961 case, Monroe v. Pape, ${ }^{23}$ the U.S. Supreme Court specifically interpreted section 1983 as allowing a remedy for Fourteenth Amendment deprivations caused by a state official's abuse of his position. ${ }^{24}$

\section{A. Proving an Underlying Due Process Violation}

School board liability under section 1983 for peer abuses requires the plaintiff to estabhish a constitutional violation of her due process rights under color of state law..$^{25}$ In cases of school abuse, the constitutional riglit at stake is the substantive due process right of bodily integrity under the Fourteenth Amendment's Due Process Clause. ${ }^{26}$ However, a due process violation will be found only if the plaintiff shows that his imjury resulted from state action. ${ }^{27}$ Altlough courts have found state action to be satisfied when a school employee assaults a student, ${ }^{28}$ they have been

Hosp., Inc., 826 F.2d 1030, 1032 (11th Cir. 1987).

22. Wideman, 826 F.2d at 1032 .

23. 365 U.S. 167 (1961).

24. Id. at 172. Largely as a result of the Court's decision in Monroe, $\S 1983$ evolved as the equivalent of a Fourteenth Amendment civil action for damages. Sheldon Nahmod, Section 1983 Discourse: The Move From Constitution to Tort, 77 GEO. L.J. 1719, 1722 (1989).

25. See 42 U.S.C. \& 1983 (1988).

26. Doe v. Taylor Indep. Sch. Dist., 975 F.2d 137, 142 (5th Cir. 1992), reh'g granted, 987 F.2d 231 (5th Cir. 1993).

27. United States v. Price, 383 U.S. 787, 794 n.7 (1966); The Civil Rights Cases, 109 U.S. $3,11,17$ (1883).

28. See, e.g., Thelma D. v. Board of Educ., 934 F.2d 929 (8th Cir. 1991); J.O. v. Alton Comm. Umit Sch. Dist. 11, 909 F.2d 267 (7th Cir. 1990); Stoneking v. Bradford Area Sch. Dist. (Stoneking II), 882 F.2d 720 (3d Cir. 1989), cert. denied, 493 U.S. 1044 (1990).

Even when constitutional liberty interests are implicated, however, not all bodily injuries caused by state actors give rise to municipal hability. Monell v. Department of Social Servs., 436 U.S. 658,694 (1978). Although by proving an underlying constitutional violation, the victim may have an action against the specific employee responsible, more must be shown before a $\S 1983$ action will lie against the school's administration or board. The plaintiff must additionally prove that the school administration in some way caused her injury-that it too violated her constitutional rights by failing to protect her froin the teacher's abuse. Consequently, the plaintiff must establish that the school board maintained a policy of deliberate indifference towards safety violations. See infra text accompanying notes $123-34$. 
much more reluctant to do so for injuries caused by other students. Very often, then, the public or private nature of the injury will ultimately determine whether the abuse suffered constitutes a due process violation.

For example, in Stoneking v. Bradford Area School District, ${ }^{29}$ a school employee abuse case, a student brought a section 1983 action agamst the school after the school's band director sexually molested her. ${ }^{30}$ On remand, the Third Circuit held that the school district could be held hable for maintaining policies that were dehiberately indifferent to the teacher's sexual abuse. ${ }^{31}$ The court also held that evidence that school supervisors discouraged and minimized reports of the teacher's sexual misconduct could lead a jury to infer a policy of condoning such behavior. ${ }^{32}$ Importantly, the court considered the teacher's abuse of the child to constitute the necessary underlying violation: "A teacher's sexual molestation of a student is an intrusion of the schoolchild's bodily integrity ... under the Due Process Clause ...." ."33

The inadequacy of a pure Stoneking theory of hability for peer abuse cases is born out in Dorothy J. v. Little Rock School District. ${ }^{34}$ In Dorothy J., the plaintiff, Brian B., attempted to hold the school board liable after a fellow student sexually inolested and raped him. At the time of the imcident, the plaimtiff was attending a special program for the mentally handicapped at a local

29. Stoneking v. Bradford Area Sch. Dist. (Stoneking D, 856 F.2d 594 (3d Cir. 1988), vacated sub nom. Smith v. Stoneking, 489 U.S. 1062 (1989), on remand sub nom. Stoneking v. Bradford Area Sch. Dist. (Stoneking II), 882 F.2d 720 (3d Cir. 1989), cert. denied, 493 U.S. 1044 (1990).

30. Stoneking II was the first case to apply the "deliberate indifference" standard of City of Canton v. Harris, 489 U.S. 378 (1989), to schools. See Stoneking II, 882 F.2d at 725-26 (citing Harris, 489 U.S. at 388-89).

31. Id. at 724-25. The court considered state action to be a requisite for liability and found that requirement to be satisfied because the violation was committed by the school's band director.

32. Id. at 730-31. Some courts have been unwilling to impute reckless indifference to school officials even in the face of overwhelming evidence of abuse. See, e.g., Thelma D. v. Board of Educ., 934 F.2d 929, 933 (8th Cir. 1991) (finding that the school board's failnre to remove a teacher in the face of five previous complaints of sexual abuse over a sixteen-year period was not actionable under $\$ 1983$ absent a showing that it had knowledge of the teacher's unconstitutional misconduct or maintained inadequate procedures for addressing cases of abuse).

33. Stoneking II, 882 F.2d at 727.

34. 794 F. Supp. 1405 (E.D. Ark. 1992), affd, No. 92-2452, 1993 WL 406464 (8th Cir. Oct. 6, 1993). 
high school. ${ }^{35}$ In refusing to hold various government agencies liable, the court remained unpersuaded by the theory used in Stoneking that the school's policies and customs directly caused the constitutional mjury. ${ }^{36}$ The principal distinction it drew was that Brian B.'s injuries resulted from another student's actions, rather than those of a scliool employee. ${ }^{37}$ According to the court, the case "lacked the linchpin of Stoneking II, namely, an underlying violation by a state actor." ${ }^{, 38}$

The court's holding implies that to establish the necessary constitutional violation, victims of peer abuse must assert that the scliool had a constitutional duty to protect students' liberty interests from private liarms. Only by establishing such a duty will the child be able to prove that an underlying due process violation has occurred. Whetlier a protective duty applies to schools is a question that has divided lower courts. Although the U.S. Supreme Court has never addressed this question, it did consider the broader issue of affirmative constitutional duties in a seminal decision, DeShaney v. Winnebago County Department of Social Services. ${ }^{39}$

\section{B. The DeShaney Watershed}

DeShaney, a 1989 U.S. Supreme Court decision, is controlling on the general question of an individual's right to receive government protection agamst due process imvasions by private actors. ${ }^{40}$

35. Id. at 1407.

36. Id. at 1409-10.

37. Id. at 1409.

38. Id. at 1410; see also Hunter v. Carbondale Area Sch. Dist., 829 F. Supp. 714, 721 (M.D. Pa. 1993) (finding school was not hable under Stoneking II for the death of a special education student at the hands of other students since no state action was involved); Elliot v. New Miami Bd. of Educ., 799 F. Supp. 818, 823 (S.D. Ohio 1992) (" $[F]$ or a court to impose $\S 1983$ liability for the state's pohicy, custom, or practice, the underlying violative acts must have been committed by state officials .... '[S]ection 1983 hability may not be ... [imposed] where private actors committed the underlying violative acts.'" (quoting D.R. v. Middle Bucks Area Vocational Technical Sch., Nos. 91-1136, 91-1137, 1991 WL 276292, affd on reh'g, 972 F.2d 1364 (3d Cir. 1992) (en banc), cert. denied, 113 S. Ct. 1045 (1993)) (alteration in original); Doe v. Douglas County Sch. Dist. RE-1, 770 F. Supp. 591, 594 (D. Colo. 1991) (holding that the school may have had a policy, custom, or practice that caused the plaintiff's harm when the school psychologist sexually molested the plaimtiff); Arroyo v. Pla, 748 F. Supp. 56,60 (D.P.R. 1990) (" $[T]$ he determining factor in this case is that the death . . . was caused solely by a private individual.").

39. 489 U.S. 189 (1989).

40. For other discussions of DeShaney, see Laura Oren, The State's Failure To Protect Children and Substantive Due Process: DeShaney in Context, 68 N.C. L. REv. 659 
In DeShaney, the state Department of Social Services received several reports that a four-year-old boy, Joshua, was being abused by his father but failed to remove him from the father's custody. Shortly thereafter, the father beat Joshua so severely that the child suffered permanent brain damage, rendering him retarded and requiring his institutionalization for life. Through his mother, Joshua sued the caseworkers and the agency for violating his substantive due process right to hberty by failing to protect him from his father. ${ }^{41}$

The DeShaney Court held that the state's failure to protect the child did not violate his substantive due process rights because there is no constitutional guarantee against private violence. ${ }^{42}$ Writing for the majority, Chief Justice Rehnquist reasoned that although the Due Process Clause forbids the state itself from infringing on civil hberties, it does not impose "an affirmative obligation on the State to ensure that those interests do not come to harm through other ineans." ${ }^{43}$

Although denying any state hability in the case before it, the DeShaney Court nevertheless conceded that a duty of protection might arise out of certain "special relationships" between the state and particular individuals. " Joshua had contended that "because the State knew that [he] faced a special danger of abuse ... and specifically proclaimed ... its intention to protect him against that danger," a special relationship was created that imposed an affirinative duty on the state to protect $\mathrm{him} .{ }^{45}$ The Court squarely

(1990); Amy Sinden, In Search of Affirmative Duties Toward Children Under a PostDeShaney Constitution, 139 U. PA. L. REv. 227 (1990); Kristen L. Davenport, Note, Claims of Abused Children Against State Protective Agencies-The State's Responsibility After DeShaney v. Winnebago County Department of Social Services, 19 FLA. ST. U. L. REv. 243 (1991); Lynne J. Stern, Comment, Young Lives Betrayed: DeShaney v. Winnebago County Department of Social Services, 25 NEW ENG. L. REv. 1251 (1991); Benjamin Zipursky, Note, DeShauey and the Jurisprudence of Compassion, 65 N.Y.U. L. REV. 1101 (1990).

41. DeShaney, 489 U.S. at 193. Specifically, the plaintiff alleged that the state's failure to remove Joshua from his home, despite the knowledge of social workers that Joshua's father was severely abusing him, coustituted a deprivation of his substantive due process uuder the Fourteenth Amendinent. Id.

42. Id. at $195,202$.

43. Id. at 195. Chief Justice Rehnquist's historical analysis of the Due Process Clause is a classic articulation of the "charter of negative liberties" theory of the Constitution. See infra notes 58-59 and accompanying text.

44. DeShaney, 489 U.S. at 197-99.

45. Id. at 197. 
rejected this contention. It concluded that the state's knowledge of a third-party danger and its willingness to aid could not serve as a basis for a special relationship. ${ }^{46}$ The only instance in which the Court exphicitly recognized a special relationship involved situations of state custody. ${ }^{47}$ Drawing on two prior decisions, Estelle $v$. Gamble $^{48}$ and Youngberg v. Romeo, ${ }^{49}$ the DeShaney Court concluded that "when the State takes a person into its custody and holds him there against his will, the Constitution imposes upon it a corresponding duty to assume some responsibitity for his safety and general well-being." ${ }^{50}$ Falling under this exception are prisoners and involuntarily committed inental patients, who are entitled to a duty of protection based on the Eighth Amendinent's prohibition against cruel and unusual purnshment and the substantive component of the Fourteenth Amendinent's Due Process Clause, respectively. For prisoners, this duty entitles them to protection froin violent acts committed by either the state or fellow inmates. ${ }^{51}$ Institutionalized mental patients also are guaranteed safe conditions of confinement. ${ }^{52}$ In carving out this exception, however, the Court was careful to narrow its application to instances in which the state's custody of an individual involuntarily has deprived him of his hiberty and ability to care for himself. ${ }^{53}$

46. Id. at 201-02. According to the Court, the origin of this "mistaken" idea can be traced back to the Supreme Court's opinion in Martinez v. California, 444 U.S. 277 (1980). DeShaney, 489 U.S. at 197-98 n.4. In Martinez, the Court was confronted with the issue of "whether state officials could be held liable under the Due Process Clause ... . for the death of a private citizen at the hands of a parolee." In dicta, the Court pointed to the fact that the parole board was not aware that the decedent faced any special danger as an additional reason for denying the plaintiffs claim. Id. (citing Martinez, 444 U.S. at 285). Several courts of appeals subsequently interpreted this language to mean that once the state learns of a danger to an identified victim and indicates a willingness to provide protection, a special relationship is created that gives rise to an affirmative duty. Id.

47. DeShaney, 489 U.S. at 198-200. By adopting a bright-line custody rule, DeShaney ostensibly brought certainty to substantive due process cases involving state unresponsiveness. Statutory responsibilities, knowledge of danger, willingness to help, likelihood of prevention, and special relationships other than those arising from custody all became extrinsic concerns.

48. 429 U.S. 97 (1976).

49. 457 U.S. 307 (1982).

50. DeShaney, 489 U.S. at 199-200.

51. See, e.g., Rhodes v. Chapman, 452 U.S. 337, $345-47$ (1981); Estelle v. Gamble, 429 U.S. 97, 102-03 (1976); Young v. Quinlan, 960 F.2d 351, 361-63 (3d Cir. 1992).

52. DeShaney, 489 U.S. at 199.

53. Id. at $199-200$. 
The DeShaney court ultimately held that the EstelleYoungberg line of analysis was not applicable to Joshua's circumstances. ${ }^{54}$ Because he was not in the state's custody at the time of mjury, the situation did not fall within the rubric of the special relationship exception. ${ }^{55}$ The court distinguished Joshua's phight from that of a foster child, wliose situation the Court felt might be sufficiently analogous to incarceration to trigger an affirmative duty to protect. It left open the possibility that the state could be held liable for failing to protect children from mistreatment by their foster parents. ${ }^{56}$

\section{The False Distinction Within the State Action Doctrine}

When a student is assaulted by a fellow student, inost courts liave refused to loold the state responsible under the Due Process Clause of the Fourteenth Amendment. ${ }^{57}$ The direct cause of the injury is a private actor, not a public employee. This distinction between state action and inaction addresses the concern that the government be held responsible only when it or one of its own agents has caused the harm in question. Still, the state actionmaction distinction does not always effectuate this policy concern. Does a seeming lack of state action automatically translate into a lack 'of state responsibility? Or can the state still bear some responsibility even in cases in which the immediate cause of the injury cannot be directly attributed to it?

The thrust of DeShaney is that the state is under no affirmative obhigation to protect individuals from private harms. This view comports with a readimg of the Due Process Clause as requiring only that the state refrain from violating citizens' constitutional riglits. ${ }^{58}$ Sucl an understanding reflects the notion that the Con-

54. Id. at 201. Chief Justice Rehnquist asserted that "[w]hile the State may have been aware of the daugers that Joshua faced in the free world, it played no part in their creatiou, nor did it do anything to render him any more vulnerable to them." Id. This statement seems to equate the absence of custody with the absence of any wrongdoing on the state's part. Thus, the Court insisted that the state neither abused its power nor placed Joshua in a worse position than he would have been in had it not acted at all by returning him to his father's custody. Id.

55. Id.

56. Id. at 201 n.9.

57. See, e.g., D.R. v. Middle Bucks Area Vocational Technical Sch., 972 F.2d 1364 (3d Cir. 1992) (en banc), cert. denied, 113 S. Ct. 1045 (1993); Russell v. Fannin County Sch. Dist., 784 F. Supp. 1576 (N.D. Ga.), affd, 981 F.2d 1263 (11th Cir. 1992).

58. The Due Process Clause of the Fourteenth Amendment provides that "[n]o State 
stitution is simply a "charter of negative hiberties." 59 Under this strict interpretation, the state has no positive duty to protect citizens against harms caused by private actors.

The tendency of courts to decide affirmative duty questions on the basis of state action has been sorely criticized. Much of this dissatisfaction comes out of recognition that the distinction between action and inaction is highly malleable. In short, the concern is that "it is possible to restate inost actions as corresponding inactions with the same effect, and to show that inaction inay have the same effects as a forbidden action." ${ }^{\prime 0}$ A neat division between the two characterizations is therefore impossible. ${ }^{61}$

In addition, inuch of the judicial resistance towards recognizing an affirmative duty absent state action arises out of fear of the "shippery slope"-that any such recognition is the first step towards the evils of big government and a general constitutional "duty to provide basic services." 62 Implicit in the slippery slope argument is the concession that imposing a duty on the governnient in the case at hand would not be objectionable. Rather, the concern is with the judges' and jurors' ability in future cases to

shall ... deprive any person of life, liberty, or property, without due process of law." U.S. CoNST. amend. XIV, § 1.

59. See Bowers v. DeVito, 686 F.2d 616, 618 (7th Cir. 1982) ("The Constitution is a charter of negative liberties; it tells the state to let people alone; it does not require the federal government or the state to provide services, even so elementary a service as maintaining law and order.").

60. Archie v. City of Racine, 847 F.2d 1211, 1213 (7th Cir. 1988), cert. denied, 489 U.S. 1065 (1989).

61. An examination of other constitutional guarantees further supports the conclusion that the action-inaction distinction is unhelpful. Even the most negatively plirased constitutional duties may be discharged solely through positive government exertions. Although the First Amendment demands only that "Congress shall make no law" abridging free speecl rights, the inere failure to enact laws curtailing speech does not absolve the govermment of its duty to protect freedom of speech. It may be required to expend resources and provide access to public forums to comply with the constitutional mandate of free speech. Susan Bandes, The Negative Constitution: A Critique, 88 MicH. L. REv. 2271, 2282 (1990). The Fourth Amendment's proscription against unreasonable search and seizure is intended to prevent the governinent from interfering in citizens' private affairs. The government can arguably fulfill this mission only by taking affirmative steps to obtain warrants based on probable cause. Another example is the Fifth Amendment's guarantee against self-incrimination and freedom from government coercion. Id. To ensure that "[n]o person ... shall be compelled in any criminal case to be a witness against himself," U.S. CoNsT. amend. V., the government is obliged to warn the accused of his rights.

62. Thomas A. Eaton \& Michael Wells, Govermment Inaction as a Constitutional Tort: DeShaney and Its Aftermath, 66 WASH. L. REV. 107, 132 (1991) (quoting Jackson v. City of Johiet, 715 F.2d 1200, 1204 (7th Cir. 1983), cert. denied, 465 U.S. 1049 (1984)). 
discern instances in which governmental protection is appropriate. ${ }^{63}$

Moreover, apart from its questionable underpinnings, the state action test is unworkable because it is subject to arbitrary application. In asking whether the state has acted to deprive a person of his rights, the test requires the court to choose a time frame for its review. Consequently, whether the state is said to liave acted largely depends on how far back in the chain of events a court is willing to look. ${ }^{64}$ The frame of reference chosen is central to the court's disposition of a plaintiff's due process claim. By limiting its focus to the period in which the sexual abuse took place, courts are able to conclude that uo due process violation has occurred since the school has taken no action causally related to the injuries during that time. Under an expanded frame of reference, lowever, including the period prior to the immediate infliction of the mjury, the scliool lias acted in a number of ways towards its students that make the custody rule espoused in DeShaney relevant for state action purposes. By takmg a person into custody and holding him against his will, the state assumes a coustitutional duty to provide for his safety. ${ }^{65}$ Such actions by the state also satisfy the state action requirement for constitutional torts. The question is thus whether compulsory sclool attendance is a form of custody sufficient to invoke the exception.

\section{DeSlianey Goes to School: The School as a Custodial Environ- ment}

The Constitution imposes on the state an affirmative duty of protection when a special relationship exists between it and particular individuals. ${ }^{66}$ The DeShaney Court was careful to limit the finding of such a duty to imstances in which the state has taken a person involuntarily into its custody, thus rendering him unable to care for himself. ${ }^{67}$ Although the state does not regularly assume

63. Id. at 132-33. The logic underlying the slippery slope argument is that by enforcing only a negative government duty to avoid direct harm, courts can sidestep sucl thorny issues as causation, motivation, duty, and the allocation of governmental and judicial resources.

64. Bandes, supra note 61 , at 2281.

65. DeShaney v. Winnebago County Dep't of Social Servs. 489 U.S. 189, 199-200 (1989).

66. Id. at 197-99.

67. Id. at 199-200. 
an affirmative obligation to protect people from private harms, an exception exists for situations of state custody.

Whether a public school constitutes a custodial setting for protective duty purposes has yet to be definitively decided. In J.O. v. Alton Community Unit School District $11,{ }^{68}$ for example, the U.S. Court of Appeals for the Seventh Circuit refused to impose an affirmative duty of care on the school under the custody exception set out in DeShaney. ${ }^{69}$ In denying section 1983 relief to a student who had been sexually abused by a teacher, the court found the compelled attendance of students to be much less debilitating than the confinement of prisoners and mental patients. ${ }^{70}$

In Doe v. Taylor Independent School District, ${ }^{71}$ however, the U.S. Court of Appeals for the Fifth Circuit did impose an affirmative constitutional duty on the school's superintendent and principal to protect students from substantive due process violations. In Doe, a high school student brought a section 1983 civil rights suit against various school personnel after her teacher engaged her in

68. 909 F.2d 267 (7th Cir. 1990).

69. The Third and Tenth Circuits agree with the Seventh Circuit that a public school does not constitute a custodial environment for purposes of $\S 1983$. See, e.g., Maldonado v. Josey, 975 F.2d 727, 731 (10th Cir. 1992) (finding that "compulsory attendance laws in no way restrain a child's hiberty so as to render the child and his parents unable to care for the child's basic needs"), cert. denied, 113 S. Ct. 1266 (1993); D.R. v. Middle Bucks Area Vocational Technical Sch., 972 F.2d 1364, 1371 (3d Cir. 1992) (en banc) (requiring children to attend school does not create a custodial relationship within the meaning of DeShaney), cert denied, 113 S. Ct. 1045 (1993); see also Robbins v. Maine Sch. Admin. Dist. No. 56, 807 F. Supp. 11, 13 (D. Me. 1992) (finding that the relationship between a state and its students is not a special custodial relationship as described in DeShaney); Doe v. Douglas County Sch. Dist. RE-1, 770 F. Supp. 591, 593-94 (D. Colo. 1991) (concluding that a public school did not have special relationship with a student so as to impose affirmative duty on the school to protect the student from sexual abuse by the school psychologist); $c f$. C.M. v. Southeast Delco School Dist., 828 F. Supp. 1179, 1189-90 (E.D. Pa. 1993) (holding that a school district's affirmative duty to protect its students froin teacher abuse derives not froin its custody of students but from its obligations to supervise the conduct of its teachers); K.L. v. Southeast Delco School Dist., 828 F. Supp. 1192, 1195-96 (E.D. Pa. 1993) (clarifying the holding in C.M. that the state has an affirmative duty to protect its students from the abusive conduct of teachers, rather than all state employees).

70. As one court noted,

By mandating school attendance for children under the age of sixteen, the state ... has not assumed responsibility for their entire personal lives; these children and their parents retain substantial freedon to act. The analogy of a school yard to a prison may be a popular one for school-age children, but we cannot recognize constitutional duties on a child's lament.

J.O., 909 F.2d at 272.

71. 975 F.2d 137 (5th Cir. 1992), cert. denied, 113 S. Ct. 1066 (1993). 
repeated episodes of sexual intercourse during her freshman and sophoinore years. ${ }^{72}$ After recognizing the child's constitutional right to be free from sexual molestation, the court found that the school had assumed a duty to protect its students by virtue of Texas's coinpulsory education statute and the school's in loco parentis status. ${ }^{73}$ Harkening back to the "deprivation of hiberty" test espoused in DeShaney, the court held,

Inasinuch as a state acquires a duty. to protect an individual when it "render[s] that individual unable to act for hinself," so too does the state acquire a duty to protect a child when it renders the guardian of that child powerless to act on the child's behalf. So, when the state has in soine significant way separated the child from the persons otherwise responsible for taking precautions to shield the child froin the social milieu, the state assumes a corresponding duty to provide that protection, for a child is ordinarily incapable of fending for himself. ${ }^{74}$

Assuming that a duty of protection has in fact been found, school personnel must still be shown to have intentionally breached this duty before the Due Process Clause is inplicated. ${ }^{75}$ Thus, mere neghigence by schools towards sexual or physical abuse is insufficient to create a due process violation. ${ }^{76}$

72. Id. at $139-41$.

73. In loco parentis describes the authority vested in schools to assume a parental role with respect to students for educational purposes. See Black's Law Dictionary 787 (6th ed. 1990) ("In the place of a parent").

74. Id. at 146 (citation omitted) (quoting Shaw v. Strackhouse, 920 F.2d 1135, 1144 (3d Cir. 1990)); see also Waechter v. School Dist. No. 14-030, 773 F. Supp. 1005, 1007-09 (W.D. Mich. 1991) (finding that a custodial relationship existed when a handicapped student died after being forced to run 350 yards in less than two minutes as punishment for talking with another classmate).

75. The degree of fault required to establish a constitutional violation is distinct from the deliberate indifference required for municipal liability. See City of Canton v. Harris, 489 U.S. 378,388 n. 8 (1989).

76. In the 1986 companion cases of Daniels v. Williams, 474 U.S. 327, 330-31 (1986) and Davidson v. Cannon, 474 U.S. 344, 347-48 (1986), the U.S. Supreme Court asserted that inere neghigence by a state official is insufficient to deprive a person of his liberty or property under the Fourteenth Amendment. Daniels and Davidson dealt with violations of procedural due process. Although the Supreme Court has left open the question of what culpability threshold will trigger substantive due process violations, lower courts have generally decided that conduct beyond mere negigence is required. See, e.g., Redman v. County of San Diego, 942 F.2d 1435, 1443 (9th Cir. 1991) (adopting "dehberate indifference" or "reckless indifference" as the level of culpability that pretrial detainees must establish for violations of their personal security interests under the Fourteenth Amendment), cert. denied, 112 S. Ct. 972 (1992). Questions of culpability often 
In recognizing a custody exception, the DeShaney Court did not expressly enumerate the factors to be used in deciding what constitutes custody. The question thus becomes what standards-legal or functional-should be employed to determine whether custody exists. Under a legal defimition of custody, a person is taken into custody when he is confined under an asserted legal authority. ${ }^{77}$ Under a functional definition, the inquiry centers on whether the state has exposed the individual to additional risk and increased her dependence on state protection. ${ }^{78}$ Both approaches provide insight into whether the relationship between schools and students rises to the level of custody.

1. The Legal Custody Perspective. A school's legal authority to confine its students originates partly from its designated in loco parentis status. Parents do not voluntarily confer this authority on school officials; rather, it is publicly mandated by local educational statutes. ${ }^{79}$ At the heart of society's "family values" lies the recogmition that a "child generally depends on his parents to guard against the dangers of his surroundings." hed on this notion to impose a similar protective obligation on the state when it has stepped into the role of a parent. ${ }^{81}$

turn on whether a public agent had knowledge or notice of the alleged injury. Thus, a school official's state of mind may very well be determinative of whether a constitutional remedy will be awarded in a due process case.

State-of-mind requirements present certain advantages to courts with conservative agendas. First, due process guarantees may be expanded or contracted on a judicial whim simply by manipulating the required state of mind. The statute's ainorphous language, "subjects" or "causes [a person] to be subjected," would reasonably support whatever state-of-mind standard courts desire. Charles F. Abernathy, Section 1983 and Constitutional Torts, 77 GEO. L.J. 1441, 1458 (1989). Second, due process clains can be passed off as generic tort actions and remanded to state court if plaintiffs fail to allege that the defendant official possessed the requisite state of mind. Nahunod, supra note 24, at 1743 .

77. See infra subsection $\mathrm{I}(\mathrm{D})(1)$.

78. See infra subsection $\mathrm{I}(\mathrm{D})(2)$.

79. See, e.g., PA. STAT. ANN. tit. 24, § 13-1317 (1992), which provides,

Every teacher, vice principal and principal in the public schools shall have the right to exercise the same authority as to conduct and behavior over the pupils attending his school, during the time they are in attendance, including the time required in going to and from their hoines, as the parents, guardians or persons in parental relation to such pupils may exercise over them.

80. Doe v. Taylor Indep. Sch. Dist., 975 F.2d 137, 146 (5th Cir. 1992), cert. denied, 113 S. Ct. 1066 (1993).

81. Id. In Doe, the U.S. Court of Appeals for the Fifth Circuit found that a special relationship between the state and a child arises in various circumstances: when a child is confined to a state inental health facility; when a social services agency removes the child 
A school's legal authority to confine children also derives from the state's compulsory education statutes. ${ }^{82}$ These statutes command students to attend schools until they reach a certam statutory age. Consequently, they are left without the option to decline attendance, and both children and their parents may be penalized for a child's truancy. ${ }^{83}$ Courts, however, have generally found compulsory school attendance laws insufficient as a basis for imposing affirmative duties on schools. The argument in favor of such a duty is that the state's truancy laws impose a restraint on schoolchildren's liberty, thereby creating a custodial relationship and a corresponding duty of care. Courts, however, are quick to distinguish the pliglit of prisoners and mental patients from that of schoolchildren. Unlike either protected group, the courts respond, students do not depend on the state to provide for their basic human needs, nor do they suffer the same degree of deprivation of their liberty. ${ }^{84}$

from her natural home and places her under state supervision; or when the child has been placed in foster care. "In these instances, the state has, to varying degrees, assumed an obligation to protect the child, in much the same way that a capable parent would." Id.

82. See, e.g., PA. STAT. ANN. tit. 24, § 13-1327. It should also be noted that school officials owe a broad common law duty to students to protect them from tortious or criminal conduct of teachers. A state law duty is not equivalent, however, to a constitutional duty. See Archie v. City of Racine, 847 F.2d 1211, 1216-19 (7th Cir. 1988).

83. See, e.g., PA. STAT. ANN. tit. 24, § 13-1333 (imposing fine and/or jail sentence on parents and guardians who violate compulsory education law).

84. Two rare instances in which the compulsory school attendance argument were found to be persuasive were Pagano v. Massapequa Pub. Sch., 714 F. Supp. 641 (E.D.N.Y 1989), and Robert G. v. Newburgh City Sch. Dist., No. 89 CIV. 2978 (RPP), 1990 WL 3210 (S.D.N.Y. Jan. 8, 1990). In Pagano, a sixth-grader who had been subjected to seventeen physical and verbal attacks by other students brought a $\S 1983$ action against school officials for failing to prevent this continued abuse. The district court ruled that students required to attend school were owed some duty of care by school authorities. Pagano, 714 F. Supp. at 643. Although not formally grounding its decision on state custody, the Pagano court compared the plaintiffs situation to that of a foster child, a situation in which the U.S. Supreme Court has not explicitly decided that there is a duty of protection. Id. at 643 (citing DeShaney v. Winnebago County Dep't of Social Servs., 489 U.S. 189 (1989)). The court also pointed to the school's role as parens patriae (parent of the country) in relation to the victim and his aggressors as a further justification for imposing a duty to care. $I d$.

Robert $G$. applied Stoneking $\Gamma$ s functional custody analysis, see infra note 99 , in imposing an affirmative duty of protection on the school. In that case, a student had been sexually assaulted by a substitute teacher whom the state knew to have a past criminal history of such sexual misconduct. According to both Stoneking $I$ and Robert G., students were deemed to be wards of the school during the time they were required to be present by the state's compulsory school attendance laws. Robert G., 1990 WL 3210, 
In D.R. v. Middle Bucks Area Vocational Technical School, ${ }^{85}$ for example, two female students sued various school officials after being repeatedly sexually molested by male classmates over a sixmonth period. The plaintiffs asserted that the combined effect of compulsory school attendance and the school's in loco parentis authority so restramed their liberty as to leave tliem in the school's custody. This deprivation of their liberty, they argued, created an affirmative duty of state protection similar to the one owed to prisoners and mental patients. ${ }^{86}$ In refusing to impose an affirmative duty on the school, the court stated that students did not face the same restraints on their liberty as other protected groups and did not depend on the state as their primary caretaker. ${ }^{87}$ "Institutionalized persons," the court said, are not "given the opportunity to seek outside help to meet their basic needs [and are o]bviously ... not free to leave." tliat students, on the otlier hand, voluntarily chose to attend schools, could rely on their parents for assistance, and were capable of leaving the school if they so desired. ${ }^{89}$ It reasoned that

[h]ere it is the parents who decide whether that education will take place in the hoine, in public or private schools .... For some, the options may be limited for financial reasons. However, even when enrolled im public school parents retain the discretion to remove the child from classes as they see fit, subject only to truancy penalties for continued periods of unexcused absence .... Moreover, ... "it [cannot] be demed that a parent is justified in witldrawing his child from a school where the health and welfare of the child is threatened." 190

at *1 (citing Stoneking v. Bradford Area Sch. Dist., 856 F.2d 594 (3d Cir. 1988), vacated sub nom. Smith v. Stoneking, 489 U.S. 1062 (1989).

More typical of the judicial response to coinpulsory school attendance laws is Russell v. Fannin County Sch. Dist., 784 F. Supp. 1576 (N.D. Ga. 1992), affd, 981 F.2d 1263 (11th Cir. 1992). In that case, the court held that a compulsory school attendance law did not impose an affirmative duty on the state to protect a student from physical attacks by another student. The court distinguished Pagano on the grounds that in that case, the school was aware of the repeated incidents of abuse and promised to correct the problem. Id. at 1583 .

85. 972 F.2d 1364 (3d Cir. 1992) (en banc), cert. denied, 113 S. Ct. 1045 (1993).

86. Id. at 1370 .

87. Id. at 1371 .

88. Id.

89. It should be noted, however, that the Pennsylvania School Board Association conceded that the school would not have allowed the child's mother to attend school to watch over the classroom or provide assistance. Id. at 1381.

90. Id. at 1371 (citations omitted) (quoting Zebra v. School Dist., 296 A.2d 748, 751 
The court concluded that the statutory grant of in loco parentis status to schools did not alter the reality that parents remain the primary caretakers for their children. Although state law invested public school teachers with authority to control and reasonably discipline students, it did not impose on them a duty to do so. ${ }^{91}$

What this argument fails to consider is the perceptions of students and their parents that children are bound to attend public school and comply with the directives of school personnel. ${ }^{92}$ The Second Restatement of Torts states that "custody is complete if the person against whom and in whose presence the authority is asserted believes it to be valid, or is in doubt as to its validity, and submits to it." ${ }^{, 93}$ Under this standard, it becomes clear that if parents and students believe the scliool's legal autlority to be coinplete, custody does in fact exist.

Most parents feel that they have hittle clioice but to send their children to public scliool and that they will be lield legally accountable if they do not. Although parents do have the right to choose low their child is educated ${ }^{94}$ the exercise of this right is subject to heavy economic constraint: private schools and home education are simply not viable alternatives for the vast majority of families. ${ }^{95}$ For all practical purposes, the will of a parent must yield to that of the state in deciding a child's educational fate. As for students, they are taught, if not forced, to accept the autlority

(Pa. 1972)). Despite the court's assertion that students are presented with various educational options, most students do not enjoy this choice. As the dissent correctly pointed out, "[f]or the vast majority of children of school age, this is no choice at all. Their families are not in a financial position to fund a private school education. Even fewer are in the rare position of being able to provide their children an adequate education at home." Id. at 1380 (Sloviter, C.J., dissenting) (footnotes omitted).

91. Id. at 1371 .

92. Cf. Lee v. Weisman, 112 S. Ct. 2649 (1992). In Lee, a high school student and her father brought suit to enjoin the recitation of a prayer at her graduation ceremony. In prohibiting the prayer, the Court acknowledged the pressures to submit to the school's authority that schoolchildren experience regardless of their personal objections: "[T]he dissenter of high school age . . . has a reasonable perception that she is being forced by the State to pray in a inanner her conscience will not allow." Id. at 2658.

93. RESTATEMENT (SECOND) OF TORTS § 41(2) (1989).

94. The Supreme Court recognized the right to direct the education of one's children in Meyer v. Nebraska, 262 U.S. 390 (1923). In Meyer, the Court determined that the "right of parents to engage [a teacher] ... to instruct their children ... [is] within the liberty of the [Fourteenth] Amendinent." Id. at 400.

95. See Middle Bucks, 972 F.2d at 1380 n.4 (Sloviter, C.J., dissenting) ("Only 12 percent of the school-age population is enrolled in private schools."). 
of their teachers. Nowhere was this more evident than in Middle Bucks. To avoid the daily abuse waiting for her in the classroom lavatory, the plaintiff repeatedly asked to use a different school bathroom. The teacher allegedly either ignored or refused her request, forcing her to use the unisex bathroom and subjecting her to the continual molestations of her male classmates. This series of events illustrates that students beheve a school's legal authority to be vahid, which in turn explains their resulting willingness to submit to it. The legal reality then of the statutory authority vested in schools is the creation of a complete and effective custodial environment. ${ }^{96}$

A duty of protection also inight have arisen in Middle Bucks because the conditions of confinement arguably exceeded those permitted under the law. In DeShaney, the Supreme Court declared that "[o]f course, the protections of the Due Process Clause, both substantive and procedural, may be triggered when the State, by the affirmative acts of its agents, subjects an involuntarily confined individual to deprivations of liberty which are not among those generally authorized by his confinement." 97 In Middle Bucks, Pemisylvamia law permitted school boards to set reasonable regulations to govern students' conduct and vested in school officials "only sucli control as is reasonably necessary to prevent infractions of disciphine and interference with the educational process." $"$ This scope of authority clearly does not encompass the confinement of the female plaintiffs to situations in which they were forced to use lavatories with members of the opposite sex. Nor does it extend to the teacher's refusal of the plaintiff's request to use another bathroom to avoid contmued sexual abuse. The

96. The willingness of some students to submit to school authority is also demonstrated by their taking part in school prayer or reciting the Pledge of Allegiance, even if doing so may be contrary to their or their families' wishes. Students experience subtle psychological pressures to participate in these rituals, pressures that go beyond direct coercion in the classic sense. Both school prayer and salutation of the flag occur "within a framework in which legal coercion to attend school (i.e., coercion under threat of penalty) provides the ultimate backdrop." Lee v. Weisman, 112 S. Ct. 2649, 2684 (1992) (Scalia, J., dissenting); see also Engel v. Vitale, 370 U.S. 421 (1962) (barring compulsory school prayer); West Virginia State Bd. of Educ. v. Barnette, 319 U.S. 624 (1943) (barring compulsory flag salute).

97. DeShaney v. Winnebago County Dep't. of Social Servs., 489 U.S. 189, 200 n.8 (1989).

98. Middle Bucks, 972 F.2d at 1371 (quoting Axtell v. Lapenna, 323 F. Supp. 1077 (W.D. Pa. 1971)). 
school thus subjected the plaintiffs to confining quarters beyond what the statute contemplated, for which it should bear responsibility.

2. The Functional Custody Perspective. A functional custody perspective looks beyond the issue of authority in determining whether a set of circumstances constitutes custody for purposes of establishing an affirmative duty. Instead, the issues of control, dependency, and vulnerabihty are the focus. Schools may be said to have functional custody of students because they restrict students' ability to protect themselves as well as their parents' ability to intercede on their behalf. ${ }^{99}$

Part of Middle Bucks's justification for denying the plaintiffs protection was that they were less dependent on the state for assistance than other groups. In elucidating this point, the court reasoned,

The state's duty to prisoners and involuntarily committed patients exists because of the full time severe and continuous state restriction of liberty in both environments. Institutionalized persons are wholly dependant [sic] upon the state for food, shelter, clothing and safety. It is not within their power to provide for themselves, nor are they given the opportunity to seek outside help to meet their basic needs. ${ }^{100}$

The court felt that students, on the other hand, were not subject to contmuous custody, remamed in the primary care of their parents, and did not depend on the state to fulfill their basic needs. Because the students were free to "leave the school building ev-

99. The notion of "functional custody" in schools was first introduced in Stoneking v. Bradford Area Sch. Dist. (Stoneking I), 856 F.2d 594, 601 (3d Cir. 1988). It was developed more extensively in Steven F. Huefner, Note, Affirmative Duties in the Public Schools After DeShaney, 90 CoLUM. L. REV. 1940, 1966-76 (1990), which this Note relies on as a basis for its "functional custody" discussion. The circumstances involved in Middle Bucks are particularly illustrative of the factors that together create situations of functional custody in schools.

100. Middle Bucks, 972 F.2d at 1371 . One coinmentator has suggested that even meinbers of the general public experience a "condition of dependence." This view asserts that the government has created a coudition of individual dependency on its services and resources over time. It owns a monopoly over law enforcement, controls access to certain resources and information, and encourages reliance on its own regulatory structure in certain areas. As gradual dependence strips people of self-help remedies, the opportunity for abuse becoines greater because harm may be perpetuated on a systematic basis. See Bandes, supra note 61 , at 2294-97. 
eryday .... after school hours," the state "thus did not deny [them] meaningful access to sources of help." ${ }^{101}$ As a result, the court concluded that the school environment did not fall within the Estelle-Youngberg custodial exception recognized in DeShaney. ${ }^{102}$

To understand the rationale behind the "deprivation of liberty" test is to understand the injustice perpetrated in Middle Bucks. In recognizing the state's obligation to protect prisoners, the U.S. Supreme Court reasoned that "because the prisoner is unable "by reason of the deprivation of his hberty [to] care for himself,' it is only 'just' that the State be required to care for him." 103 The Court later extended this protection to mental patients reasoning that "[i]f it is cruel and unusual punishment to hold convicted crimimals in unsafe conditions, it must be unconstitutional [under the Due Process Clause] to confine the imvoluntarily committed-who may not be punished at all-in unsafe conditions."104 Through its compulsory attendance law, Middle Bucks School similarly confined the two female plaintiffs to dangerous quarters, rendering them defenseless against the sexual abuse awaiting then. A logical extension of the Supreme Court's reasoning dictates that the school had a duty to provide a safe educational environment for these innocent and otherwise unprotected children. By refusing to recognize this duty, the Middle Bucks court denied the plaintiffs the protection that the Constitution afforded thein, in blatant disregard of the "deprivation of hberty" standard delineated in DeShaney. ${ }^{105}$

Moreover, the notion that schoolchildren are soniehow different from other protected classes is not a persuasive justification for the disparate treatnient that they receive. It is simply untrue that students face any less of a deprivation of their liberty than prison-

101. Middle Bucks, 972 F.2d at 1372.

102. Id.

103. DeShaney v. Winnebago County Dep't. of Social Servs., 489 U.S. 189, 199 (1989) (quoting Estelle v. Gainble, 429 U.S. 97, 104 (1976)).

104. Id. (quoting Youngberg v. Roineo, 457 U.S. 307, 315-16 (1982)) (alteration in original).

105. Nowhere in DeShaney does the Court limit the finding of a duty of protection only to situations of involuntary, round-the-clock, legal custody. The Third Circuit had previously read DeShaney as acknowledging that similar state-imposed restraints on personal liberty, in addition to imprisonment and institutionalization, would trigger a duty to prevent harm. Middle Bucks, 972 F.2d at 1379 (Sloviter, C.J. dissenting) (citing Horton v. Flenory, 889 F.2d 454, 458 (3d Cir. 1989)). 
ers or mental patients. The mere fact that they are free to leave the confimes of the school at the conclusion of the school day does not make them any less of a prisoner to the school's policies durmg the time that they are there. ${ }^{106}$ Nor does it render them any less vulnerable to attacks from other students with whom they are confined. In short, tlie court's attempt to rationalize a demal of protection to students fails to acknowledge a true understandimg of the nature of confinement and the important liberty interests that it burdens.

The court of appeals' insistence that schoolchildren care for themselves or solicit the aid of their parents shows a lack of understanding of the degree of dependency. In asserting that schoolchildren should practice self-reliance, the three-judge panel that first decided Middle Bucks declared that "[t]o the extent that the child is able to take care of himself or herself, attending school does not effectively preempt that responsibility."107 The court thereby confused the responsibility to care for oneself with the capacity to care for oneself. ${ }^{108}$

In Middle Bucks, one of the victims, L.H., exercised both remarkable responsibility and courage by allegedly bringing her complaints to the attention of a school administrator. Her continued exposure to sexual abuse indicates that she simply lacked the capacity to protect herself. As for the plamtiff, D.R., she qualified as an "exceptional student" because she suffered from a hearing impairment and had difficulty communicating. Her disabilities undoubtedly imterfered with her ability to seek outside help. ${ }^{109}$ If

106. But see Ingraham v. Wright, 430 U.S. 651, 670 (1977) ("Though attendauce may not always be voluntary, the public school remains an open institution. Except perhaps when very young, the child is not physically restrained from leaving school during school hours; and at the end of the school day, the child is invariably free to return home.").

107. D.R. v. Middle Bucks Area Vocational Technical Sch., Nos. 41-1136, 91-1137, 1991 WL 276292, at *6, (3d Cir. Dec. 31, 1991), affd on reh'g, 972 F.2d 1364 (3d Cir. 1992) (en banc), cert. denied, 113 S. Ct. 1045 (1993).

108. The dissent in Middle Bucks poimted out that elementary scliool children have not yet gained sufficient independence of school authorities to complain in prompt fashion about constitutional deprivations they encounter at school. Middle Bucks, 972 F.2d at 1381 (Sloviter, C.J., dissenting). This madequate capacity may pertain to older children in similar situations as well. In fact, it is common knowledge that even adult women who have been sexually assaulted are reluctant to come forward given the private issues involved. Id.

109. D.R. had already been removed from a regular public school before coming to Middle Bucks School. She alleged that she was unable to disclose the assaults because of lier disability and her fear that if she complained about the brutahity, she would be re- 
anything, her status as an exceptional student only increased her dependence on the state for assistance and should have alerted the school to her greater need for protection. Confined to the graphic arts classroom, the plaintiffs were unable to halt the sexual abuse they encountered from their male classmates. Denying this reality, the Middle Bucks ruling can be explained only by the court's failure to perceive the disabling effect of compulsory education on the plaintiffs' ability to care for themselves.

Under DeShaney, an affirmative protective duty also may be based on the school's role in exposing its students to danger. ${ }^{110}$ In explaining its refusal to find an affirmative duty of protection, the DeShaney Court remarked that "[w]hile the State may have been aware of the dangers that Joshua faced in the free world, it played no part in their creation, nor did it do anything to render him more vulnerable to then." mated that despite its refusal to come to Joshua's aid, the state played no part in creating the domestic environment in which the harm took place. Post-DeShaney courts have adopted this statecreated danger theory, focusing their inquiry on whether the state has affirmatively acted to create the danger to the victim or $\dot{m}$ crease lins vulnerability to it. ${ }^{112}$

In contrast to the domestic abuse scenario presented in DeShaney, school abuse occurs in an environment that the state

moved from the class and would have nowhere else to go to school. Id.

110. See, e.g., Stauffer v. Orangeville Sch. Dist., No. 89-C-20258, 1990 WL 304250 (N.D. Ill. May 17, 1990). In Stauffer, the court recognized a special relationship that gave rise to a protective duty when the state placed a student in a dangerous situation. In that case, a mentally handicapped student was molested by another student in a bathroom during a school field trip to a local mall. The victim alleged that the teacher knew or should have known that the other student had made threats against him in the past and had previously been arrested for criminal sexual misconduct. Id. at *1. The court began its analysis by holding that the state's compulsory school attendance law did not create a general deprivation of liberty comparable to that imposed on prisoners or mental patients. It reasoned that "[i]f this were the case then every time a school child is assaulted by the class bully during recess there would be a tort of constitutional dimensions under \& 1983." Id. at *5.

Despite holding that no general duty existed, the Stauffer court did hold that state actors have a duty to protect a person from the violence of others if the state places that person in a position of danger. It concluded that by allowing the child to use the bathrooin with another student who was known to be dangerous, the teacher placed the child in a hazardous situation for which the school was liable. Id. at *6.

111. DeShaney v. Winnebago County Dep't of Social Servs., 489 U.S. 189, 201 (1989).

112. See, e.g., Bryson v. City of Edmond, 905 F.2d 1386, 1392-93 (10th Cir. 1990). 
both creates and regulates. ${ }^{113}$ The state in Middle Bucks, for example, initially exposed the victims to undue risk by creating a dangerous classrooin environment. The school designed the physical layout of the classrooin, which contained both a darkrooin and a single bathroom. Although not inherently dangerous, the classrooin soon became dangerous as a result of inadequate supervision. The school placed an inexperienced teacher in charge, who failed to deal properly with inale students' repeated misbehavior. The teacher herself was subjected to "open lewdness" by one male student, was allegedly present when plaintiff D.R. was forcibly dragged into the bathrooin, and was aware on at least one occasion that students of both sexes were in the bathroom together. Her general reaction was simply to ignore the behavior, walk away, or dismiss it as "those boys and their raging hormones."

Having thus created an environment that allowed sexual violence to flourish, the school invited further deviance through various displays of neglect. The teacher refused to allow D.R. to use a bathrooin elsewhere in the school, rendering her that inuch unore vulnerable to unending sexual assaults. ${ }^{115}$ Other school officials who allegedly also knew about the misconduct in the graphic arts classroom refused to remedy the situation. Plaintiff L.H. clamied that she reported an atteinpted sexual attack to the school's assistant director, but her plea for help fell on deaf ears. ${ }^{116}$ This apparently widespread and deinonstrated indifference by school persomiel heightened the victims' vulnerability to the recurring, mightunarish sexual episodes.

Framing the analysis as one of state-created danger demands revisiting the state action doctrine. In cases of peer abuse, courts often limit their focus to the period in which the sexual abuse took place, rather than examining the entire relationship between a school and its students. By doing so, they may conclude that a due process violation is lacking since the school did not act to cause the abuse during that time. This narrow inquiry, however, demies the reahity that the school's actions prior to that time contributed substantially to the resulting sexual molestation. Requiring

113. Huefner, supra note 99 , at 1968.

114. D.R. v. Middle Bucks Vocational Technical Sch., 972 F.2d 1364, 1378 (3d Cir. 1992) (en banc), cert. denied, 113 S. Ct. 1045 (1993).

115. Id. at 1380.

116. Id. at 1366 . 
the two female students to attend the school, forcing them to share bathroom facilities with male classmates, and placing a student-teacher in charge of a particularly unruly class all constituted actions by the state that seriously jeopardized the plaintiffs' bodily integrity. It was only after this active intervention in the plaintiffs' hives that the state decided to pursue a policy of inaction and apathy towards the sexual abuse that allegedly had come to its attention. That policy of inaction cannot protect the state from liability. As Judge Posner declared in Bowers v. DeVito,

If the state puts a man in a position of danger from private persons and then fails to protect him, it will not be heard to say that its role was merely passive; it is as much an active tortfeasor as if it had thrown him into a snake pit. ${ }^{117}$

It follows that Middle Bucks School could not first usher students through its gates and later seek to disclain any responsibility for the harm that befell them behind closed doors. ${ }^{118}$

\section{MUNICIPAL LIABILITY UNDER SECTION 1983}

\section{A. School Board Liability}

Under section 1983, a plaintiff can seek money dainages for peer abuse from either an individual school employee or the school board. Because school boards lave comparatively greater resources, plaintiffs will likely atteinpt to pursue claims against school boards. In Monell v. Department of Social Services, ${ }_{119}^{19}$ the U.S. Supreme Court recognized municipal liability and held that municipalities, including school boards, could be considered "persons" within the meaning of section $1983 .{ }^{120}$ Municipalities, more-

117. 686 F.2d 616, 618 (1982).

118. As Justice Brennan stated in DeShaney,

[T]he Due Process Clause of the Fourteenth Amendment was imtended to prevent government "from abusing [its] power, or employing it as an instrument of oppression." My disagreement with the Court arises from its failure to see that inaction can be every bit as abusive of power as action, that oppression can result when a State undertakes a vital duty and then ignores it. Today's opinion construes the Due Process Clause to permit a State to displace private sources of protection and then, at the critical moment, to shrug its shoulders and turn away from the harm that it has promised to try to prevent.

DeShaney v. Winnebago County Dep't. of Social Servs., 489 U.S. 189, 211-12 (1989) (Brenann, J., dissenting) (quoting id. at 196 (quoting Davidson v. Cannon, 474 U.S. 344, 348 (1986) (alteration in original))).

119. 436 U.S. 658 (1978).

120. Id. at 690 . The Court thus overruled its earlier decision in Monroe v. Pape, 365 
over, have not been accorded qualified immunity for their constitutional violations, even when such violations are committed in good faith. ${ }^{121}$

Recognition of an affirmative duty of protection, ${ }^{122}$ however, does not automatically translate into recovery for victims of peer abuse. Rather, in order to prevail against a school board under section 1983, a plaintiff nust establish that the enforcement of a school board's policy or custoni ${ }^{123}$ was the "nroving force" behind the violation of a student's substantive due process rights. ${ }^{124}$

U.S. 167 (1961), to the extent that Monroe had held that municipalities were immune from $\S 1983$ suits. See id. at 187.

121. Owen v. City of Independence, 445 U.S. 622, 650-51 (1979). Although also subject to liability, an individual school administrator enjoys qualified immumity "under the statute as long as he conducts himself in good faith." Id. at 657. If, however, an employee's conduct "violate[s] clearly established statutory or constitutional rights of which a reasonable person would have known," the administrator may then be held personally liable. Harlow v. Fitzgerald, 457 U.S. 800,818 (1982). In granting qualified immunity to individual officials while denying it to school boards, courts have recognized the increasing importance of equitable loss spreading for questions of government responsibility. The costs of official imisconduct in $\S 1983$ cases must be distributed among three different parties: "[T]he victim of the constitutional deprivation; the officer whose conduct caused the injury; and the public, as represented by the municipal entity." Owen, 445 U.S. at 657.

122. For a discussion of the affirmative duty of protection, see supra Section I(D).

123. A string of decisions, replete with widely divergent interpretations of the "official policy" standard, has followed Monell. In attempting to define further "what the full contours of municipal liability under $\S 1983$ may be," Monell, 436 U.S. at 695, postMonell courts have been largely unsuccessful in determining which types of misconduct fall under the statute's unibrella. See, e.g., City of St. Louis v. Praprotnik, 485 U.S. 112, 127 (1988) (attributing supervisor's adverse personnel decisions to the city when such decisions were considered "final" and not reviewed by higher-ranking officials); Pembaur v. City of Cincinnati, 475 U.S. 469,480 (1986) (finding that a single decision by an official with policymaking authority ' $m$ a certain area may constitute official policy and be attributable to the government entity); City of Oklahouna City v. Tuttle, 471 U.S. 808, 823-24 (1985) (noting that a simgle incident of police misconduct, by itself, does not constitute a policy of inadequate training for the purpose of ununicipal liability).

124. Polk County v. Dodson, 454 U.S. 312, 326 (1981) (quoting Monell, 436 U.S. at 694). Because mumicipalities bear $\S 1983$ habihty only for their policies and customs, it becomes necessary to identify exactly who makes municipal policy. Normally, a municipal entity formulates pohicy through its lawmaking body. For example, the U.S. Court of Appeals for the Tenth Circuit held a school district responsible for the decisions of its board of trustees because the district could only act through its board. Stoddard v. School Dist. No. 1, 590 F.2d 829, 835 (10th Cir. 1979). If certain school officials can be considered "policymakers," then hability may be attributed to the school board for the failure of those individuals to deal adequately with student safety.

Identifying which school officials occupy policymaking positions can be a thorny endeavor. By defimition, however, the number of people potentially implicated is limited to those officials possessing the necessary policymakimg authority. This circle of liability 
It is highly improbable, however, that a school board would adopt a formal "policy" of inaction towards school safety. Recognizing that not all culpable conduct flows from formal policy, Monell declared that section 1983 municipal liability may be based on a "governmental 'custom' even though such custom has not received formal approval through the body's official decisionmaking channels." 125 Thus, a school board's indifferent attitude towards safety may reflect a practice that is so widespread and permanent that it represents a de facto policy. ${ }^{126}$ Such a policy will be attributed to the school when "the duration and frequency" of the abuse "warrants a finding of either actual or constructive knowledge" by the school board or policymakers charged with the supervision of

has been further restricted to include only those officials who possess "final authority to establish municipal policy with respect to the action ordered." Pembaur, 475 U.S. at 481. There is little problem, of course, if a particular school official has been expressly delegated policymaking authority. The difficulty arises when an official's action or inaction seems to reflect school board policy without any express delegation.

One commentator has argued persuasively that the official policy formulation ignores the basic realities of bureaucratic decisionmaking and is therefore unworkable. See Peter H. Schuck, Municipal Liability Under Section 1983: Some Lessons from Tort Law and Organization Theory, 77 GEO. L.J. 1753, 1772-79 (1989). On a general level, the doctrine reflects a misapprehension of the "nature of policy" and the "locus of policymaking." $1 d$. at 1777 . This unduly restrictive conception of policymaking is especially true in the case of "street-level" bureaucracies, like schools and police departments, in which low-level employees interact with the public "on the street." Id. at 1778. In schools, the daily demands of school life often require teachers and school administrators to make decisions of tremendous consequence. Thus, a decision made by personnel outside the formal locus of policymaking can itself constitute policy or custom, a reality that the official policy standard fails to recognize. See id. The shaping or creation of a policy or custom in this informal manner raises questions regarding the viability of the official policy or custom requirement. Its failure to capture the true nature of organizational decisionmaking perpetrates a twin evil: it denies governmental accountability for its actions and refuses federal rekief to which plaintiffs with bona fide clains are entitled. See id. at $1778-79$.

125. Monell, 436 U.S. at 690-91. To limit the use of custon1-based liability, lower courts have generally required nore than an isolated incident of wrongdoing. Instead, the existence of a pattern or series of wrongful acts is necessary to establish a custom that fairly represents official policy. Schuck, supra note 124 , at 1761 n. 40.

126. MARTIN A. SCHWARTZ \& JOHN E. KIRKLIN, SECTION 1983 LITIGATION 76 (1986); cf. DiLoreto v. Borough of Oaklyn, 744 F. Supp. 610 (D.N.J. 1990). In DiLoreto, a police officer's visual observation of a detainee urinating, in the absence of suspicious circumstances, was found to violate the detainee's civil rights. The court found that the borough's failure to promulgate a formal policy on the accompanying of detainees to the bathroom did not absolve it of liability. The court reasoned that "[h]aving no policy is itself a policy, and in this case, it is an unconstitutional policy. By not creating and implementing a policy and not training its employees regarding accompanying detainees to the bathroom, the Borough has expressed dehiberate indifference to the fourth amendnent rights of detainees...." Id. at 624 . 
schoolchildren. ${ }^{127}$ Precedent indicates that acts of omission, as well as acts of commission, may support a finding of policy or custom. ${ }^{128}$

When a plaintiff seeks to show a school board's custom through omission, the inaction of the school board must amount to deliberate indifference towards due process rights before liability will be permitted under section 1983. ${ }^{129}$ The U.S. Supreme Court recently elucidated this principle in City of Canton v. Harris. ${ }^{130}$ In Canton, the plaintiff brought a section 1983 due process claim against the city after the police departinent failed to provide her with necessary medical assistance after her arrest. ${ }^{131}$ The Court ruled that a municipahty could be lield hable for inadequate police training only when "the failure to train amount[ed] to deliberate indifference to the rights of persons with whom the police come into contact."132 Such a rule comported with the Court's pronouncement in Monell that inunicipal pohicy inust be the "moving force" belind the constitutional violation under section $1983 .{ }^{133}$ The Court concluded that "[o]nly where a municipahity's failure to train its employees in a relevant respect evidences a 'deliberate imdifference' to the rights of its inhabitants can such a slortcoming be properly thought of as a city 'policy or custom' that is actionable under [section] 1983."134

127. Spell v. McDaniel, 824 F.2d 1380, 1387 (4th Cir. 1987), cert. denied, 484 U.S. 1027 (1988). For those plaintiffs nnable to establish official policy or custom and therefore ineligible for municipal rehef, the option of proceeding against the individual officials directly responsible is another avenue open to tlrem. Whether individual liability is a viable alternative, however, is questionable in hight of the extensive immunities officials enjoy and their limited resources. See Sclruck, supra note 124, at 1755 n.11.

128. See Karen M. Blum, Monell, DeShaney, and Zinermon: Official Policy, Affirmative Duty, Established State Procedure and Local Government Liability Under Section 1983, 24 CReighton L. Rev. 1, 5-6 (1990); see also Leach v. Shelby County Slieriff, 891 F.2d 1241, 1247 (6th Cir. 1989) (liolding that the plaintiff had established a "policy . . . of deliberate indifference to the medical needs of paraplegic and pliysically incapacitated prisoners"), cert. denied, 495 U.S. 932 (1990); Cabales v. County of Los Angeles, 864 F.2d 1454, 1461 (9th Cir. 1988) (finding that the county's failure to provide adequate medical care to inmates demonstrated an unconstitutional policy or custoin of deliberate indifference to inmates' medical and psychological needs), vacated, 490 U.S. 1087, reinstated, 886 F.2d 235 (9th Cir. 1989).

129. City of Canton v. Harris, 489 U.S. 378, 388 (1989).

130. 489 U.S. 378 (1989).

131. Id. at 381 .

132. Id. at 388 .

133. Id. at 388-89 (citing Polk County v. Dodson, 454 U.S. 312, 326 (1981); Monell v. Department of Social Servs., 436 U.S. 658, 694 (1978)).

134. Id. at 389. In assessing these requirements, consideration should be given to how 
In practice, proving that a school board's deliberate indifference amounts to a custom or policy is a difficult hurdle for plaintiffs to overcome. ${ }^{135}$ This difficulty nay be the result of the increasing wariness on the part of courts, since Monroe was decided, to open up the section 1983 floodgates to any and all clains. ${ }^{136}$ Indeed, the Supreme Court has repeatedly cautioned that the Fourteenth Amendinent's Due Process Clause "does not transform every tort committed by a state actor into a constitutional violation." ${ }^{137}$ The fear that an expansive reading of the Due Process Clause would relegate section 1983's status to that of a mere tort statute has contributed to courts' restrictive approach to due process claims. ${ }^{138}$ The reluctance to grant federal rehef is especially

well they effect the legislative purpose of the statute. The primary aim of $\S 1983$ was to provide protection to those injured by the "[m]isuse of power, possessed by virtue of state law and made possible only because the wrongdoer is clothed with the authority of state law." Monroe v. Pape, 365 U.S. 167, 184 (1961) (quoting United States v. Classic, 313 U.S. 299, 326 (1941)). Congress thus created an express federal remedy to enforce the Fourteenth Amendment against abusive practices by those carrying a badge of state authority. Owen v. City of Independence, 445 U.S. 622, 650-51 (1979). In keeping with this purpose, school boards were denied qualified immunity for official transgressions. See supra notes 120-21 and accompanying text. Said the Court,

How "uniquely amiss" it would be ... if the government itself-"the social organ to which all in our society look for the promotion of liberty, justice, fair and equal treatment, and the setting of worthy norms and goals for social conduct"-were permitted to disavow liability for the injury it has begotten.

Owen, 445 U.S. at 651 (citing Adickes v. S.H. Kress \& Co., 398 U.S. 144, 190 (1970)).

135. See, e.g., Black v. Indiana Area Sch. Dist., 985 F.2d 707 (3d Cir. 1993) (finding that school superintendent was not dehiberately indifferent to sexual abuse claim when superimtendent contacted parents, launched an investigation into the allegations, and took immediate action against those responsible). But see C.M. v. Southeast Delco Sch. Dist., 828 F. Supp. 1179 (E.D. Pa. 1993) (finding that school officials' response to reports of teacher's conduct amounted to dehberate imdifference to student's constitutional rights).

136. Cf. Sessions v. Livingston Parish Sch. Bd., 501 F. Supp. 251 (M.D. La. 1980) (dismissing First and Fourteenth Amendment claims that landicapped children had been deprived of meaningful, free, and appropriate public education, brought under $\S 1983$, because of a failure to exhaust administrative remedies).

137. DeShaney v. Wimnebago County Dep't of Social Servs., 489 U.S. 189, 202 (1989) (citing cases). The DeShaney court went on to say that "[a] State may, through its courts and legislatures, impose such affirmative duties ... a as it wishes. But not 'all common law duties owed by government actors were ... constitutionalized by the Fourteenth Amendment.'" Id. (quoting Daniels v. Williams, 474 U.S. 327, 335 (1986)).

138. Lower federal courts also have employed procedural mechanisms to insulate municipalities from $\S 1983$ actions. The U.S. Court of Appeals for the Fifth Circuit, for example, adopted a "heightened pleading standard" that required § 1983 complaints against municipal corporations to state the basis of the claim with factual detail and particularity. Part of the justification for the rule is one of efficiency; a more relaxed pleading standard would subject nunicipalities to costly and time-consuming discovery in every 
strong in those cases in which state remedies are considered adequate. ${ }^{139}$

Section 1983's requirements for mumcipal liability are aimed at ensuring that the municipality caused the constitutional deprivation. Causation questions often become complicated because some causal link between the mumicipality and the mjury is present in most cases. ${ }^{140}$ Thus, an inquiry premised on finding the absolute cause of an injury is an exercise in futility. ${ }^{141}$ What must be ascertamed instead is the substantiality of the nexus between the state and the ijjured party. ${ }^{142}$ It is only this latter imquiry that truly addresses the issue of government responsibility. ${ }^{143}$

Standards that demand proof of an explicit policy or high level of culpability on the scliool's part exemplify the judicial ideology that a close causal nexus must necessarily be established before fault will be ascribed to the government. The Supreme Court has concluded that the government may not be held hable under section 1983 merely because it employs a tortfeasor. ${ }^{144}$ In rejecting the notion of government liability predicated on respon-

$\S 1983$ case. The court felt that this burden would undermine municipal protections from suit and hamper mumicipal functions. See, e.g., Elliot v. Perez, 751 F.2d 1472 (5th Cir. 1985).

In a recent decision, however, the U.S. Supreme Court invalidated "heightened pleading requirements" in § 1983 cases alleging municipal hability. See Leatherman v. Tarrant County Narcotics Intelligence and Coordination Umit, $113 \mathrm{~S}$. Ct. 1160 (1993). The Court found that the asserted justification wrongly equated "freedom from liability witl immunity from suit." Id. at 1162. Reaffirming its position in Monell, the Court reasoned that although a mumicipality is not subject to $\S 1983$ hability on a respondeat superior basis, this protection "does not encompass immunity from suit." Id.

139. For example, in Paul v. Davis, 424 U.S. 693 (1976), § 1983 relief was denied to a plaintiff who claimed that law enforcement officers had damaged his reputation by publicly branding him an active shoplifter. The Court placed the plaintiff's reputation interest among the many that states could adequately protect through tort law, which provided "a forum for vindication of those interests by means of damages actions." Id. at 712 .

140. Schuck, supra note 124 , at $1764-65$.

141. As las been noted,

[O]nce events are set in motion, there is, in terms of causation alone, no place to stop. The event without millions of causes is simply inconceivable; and the mere fact of causation, as distinguished from the nature and degree of the causal connection, can provide no clue of any kind to singling out those which are to be held legally responsible.

IV. PAGE KeEton eT AL., PROSSER \& KeETON ON THE LAW OF TORTS \& 41, at 266 (5th ed, 1984).

142. Schuck, supra note 124 , at 1765 .

143. Id.

144. Monell v. Department of Social Servs., 436 U.S. 658, 691-92 (1978). 
deat superior, the Court has reasoned that it is simply incompatible with the causal language of the statute. ${ }^{145}$

\section{B. Implications of the Deliberate Indifference Standard}

Requiring deliberate indifference of school boards to establish a due process violation encourages the boards to bureaucratically remove themselves from daily school affairs. In Thelma $D$. $v$. Board of Education, ${ }^{146}$ elementary school students who were sexually abused by a teacher brought suit agamst the school board under section 1983. Despite five previous complaints of sexual abuse lodged agamst the teacher over a sixteen-year period, the U.S. Court of Appeals for the Eighth Circuit held that the school board could not be held liable. ${ }^{147}$ Among the reasons the court gave for its decision was a conclusion that the board did not demonstrate deliberate indifference or tacit authorization of the sexual misconduct. ${ }^{148}$ The school's admmistrative procedures designed to address child abuse apparently allowed only a limited amount of information to reach the school board. ${ }^{149}$ In dicta, the court commented that "[w]ithout notice of the prior incidents, the Board . . . cannot be said to have shown deliberate imdifference towards [the teacher's sexual] misconduct."150 Under such a scheme, a school board avoids punishment simply by maintaining a general policy of iguorance towards the misconduct taking place on its doorstep.

The Thelma $D$. court openly recognized the inconpatibility of societal goals with the disincentives for agency involveinent the statute provided. In identifying this troubling "conflict of interests," the court reasoned,

In order to more effectively protect the constitutional rights of its students, the Board must possess a greater knowledge and awareness of incidents involving misconduct by its employees. This greater knowledge ... [h] owever ... also subjects the Board to liability for displaying deliberate indifference should it fail to sufficiently reinedy the problem. ${ }^{151}$

145. Id.

146. 934 F.2d 929 (8th Cir. 1991).

147. Id. at $931-33$.

148. Id. at 934 .

149. Id. at 935.

150. Id. at 934.

151. Id. at 935 . 
"The magnitude of the tragedy"152 in Thelma $D$. also moved the court to sound a warning to school boards and other public agencies.

In the future, this court will closely scrutinize bureaucratic hierarchies which, in their operation, tend to insulate its policymaking officials froin knowledge of events which may subject them to [section] 1983 hability. This case . . compels us to provide clear warning to the Board that in the future a defense of no liability due to lack of knowledge may no longer apply to a bureaucracy which continues to block notice to the Board of allegations of sexual abuse of students committed by teachers and others during school related activities. ${ }^{153}$

Equally disturbing is the consistent willingness of federal courts to categorize school behavior as neghigent, and therefore not a basis for liability, when it truly warrants a finding of reckless indifference. In Middle Bucks, ${ }^{154}$ for example, one of the plaintiffs allegedly told the school's assistant director that another student was trying to force her into the batliroom for sexual purposes. The Third Circuit's characterization of the school's conduct is typical of the sympathetic yet dismissive reaction of many courts.

We readily acknowledge the apparent indefensible passivity of at least some school defendants under the circumstances. Accepting the allegations as true, viz., that one school defendant was advised of the misconduct and apparently did not investigate, they show nonfeasance but they do not rise to the level of a constitutional violation. ${ }^{155}$

One wonders what degree of indifference would have amounted to misfeasance in the court's estimation. Indeed, would anything short of the school's actual participation in the imcident have been considered constitutionally offensive ${ }^{156}$

152. Id. at 936 .

153. Id.

154. D.R. v. Middle Bucks Area Vocational Technical Sch., 972 F.2d 1364 (3d Cir. 1992) (en banc), cert. denied, 113 S. Ct. 1045 (1993).

155. Id. at 1376.

156. School liability cases brought as state tort actions have been dispensed with in a similar manner. In Booker v. Chicago Bd. of Educ., 394 N.E.2d 452 (Ill. App. Ct. 1979), for example, a ten-year-old girl brought suit against the school board and her teacher after she was physically assaulted by a group of her classmates in a bathroom. The teacher had assigned as the bathroom momitor the student whom the plaintiff had pre- 
The decision of a recent prison case sheds some light on what circumstances of peer abuse conform to section 1983's requirement. In Redman v. County of San Diego, ${ }^{157}$ a pretrial detainee sued the county and county jail personnel under section 1983 after being confmed to a holding cell with a homosexual who later raped him. The offending inmate was twenty-seven years old, stood approximately 5'11" tall, and weighed 165 pounds. Prison officials knew that he was aggressive and had a reputation for coercmg and manipulating other inmates for sexual favors. The plaintiff, by comparison, was then eighteen years old, stood 5'6" tall, and weighed approximately 130 pounds. On his arrival at the detention facility, he was originally placed in a receiving area designated as the "young and tender" umit but later was transferred in with the general jail population, where the rape took place..$^{158}$

The U.S. Court of Appeals for the Ninth Circuit first found that the plaimtiff's right to personal security had been violated by the deliberate indifference of prison officials. ${ }^{159}$ It observed that "if ... officials know or should know of [a] particular vulnerability, then the Fourteenth Amendment inposes on them an obligation not to act with reckless indifference to that vulnerabihty." 160

viously identified as the leader of a group of classmates who had threatened her. Id. at 453. The Illinois appellate court held that the complaint had failed to establish that the teacher's actions constituted willful and wanton conduct for which a defense of immunity would not apply, finding that there was no evidence suggesting that the teacher had intentionally breached her duty to supervise the plaintiff. Id. at 455 . It also concluded that the teacher had no knowledge that the plaintiff faced an impending danger from entering the bathrooin unaccompanied. Id. Finally, the court noted that although the teacher may have been neghigent in naming the "gang" leader as monitor, such action did not amount to willful and wanton conduct. Id. Noteworthy is the dissenting judge's adinonishinent that "[u]nless the Board protects its students against known extortionists, our public schools are in danger of deteriorating into a jungle." Id. at 455-56 (Simon, J., dissenting).

157. 942 F.2d 1435 (9th Cir. 1991), cert. denied, 112 S. Ct. 972 (1992).

158. Id. at $1437-38$.

159. See also Young v. Quinlan, 960 F.2d 351, 362 (3d Cir. 1992) (“[P]laintiff has also presented sufficient, uncontested evidence to raise a genuine question of fact as to whether ... prison officials were dehiberately indifferent to inmate's repeated physical attacks on [him].") (citation omitted); cf. Rogers v. State of Ala. Dep't of Mental Health and Mental Retardation, 825 F. Supp. 986, 992 (M.D. Ala. 1993) (finding genuine issues of material fact existed as to whether supervisors knew or should have known that their subordinates were inadequately monitoring mental patients, one of whom was raped by another patient, and whether by failing to remedy this inadequate security, they acted with dehiberate indifference to patient's constitutional right to adequate security).

160. Redman, 942 F.2d at 1443 (quoting Colburn v. Upper Darby Township, 838 F.2d 663, 669 (3d Cir. 1988), cert. denied, 489 U.S. 1065 (1989)). 
The court based its finding that officials knew of the plaintiff's vulnerability on his original placement in the "young and tender" unit. The court also found evidence that the plaintiff's right to personal security may have been infringed as a result of the county's policy or custom of overcrowding the prison, such that heterosexual inmates were confined with aggressive homosexuals. ${ }^{161}$

In light of the liarms befalling students today, many schools are more of a close cousin to detention facilities than a distant relative. For example, nearly 1000 students a year unust be reentered im one Sacrainento school district after completing terms in juvenile detention centers. ${ }^{162}$ It seems reasonable to ask just how different these conditions are from those presented in Redman-a forced integration of known offenders with the young and defenseless. Limited resources may leave school planners with little alternative. This financial reality, however, does not deny the existence of the school's policy, it only explams it.

The sleer volunie of the problein is understandably overwhelming to teacliers and school boards. Policing a seeinimgly endless supply of youthful deviants may tax even the most resilient of educators. How else inay we reconcile the apathy of the Middle Bucks School personnel with the repeated sexual molestations that they witnessed? The constitutional mandate discussed in Redman, however, knows no such excuses. Sclools boards today cannot lielp but be aware of their students' vulnerability, and the Due Process Clause therefore requires that they not remain recklessly indifferent towards it.

\section{CONCLUSION}

D.R. v. Middle Bucks Area Vocational Technical School exemplifies the injustice that results froin a restrictive view of due process guarantees. By exculpating the school board for its supposed inaction, the court allowed the school to act with inpunity in setting its policies and rewarded its callous indifference to the sexual nnisconduct taking place on its doorstep. The message conveyed to the victins and their parents was that the scliool was a place not to be reared, but rather to be feared. Long lieralded as

161. Id. at 1444.

162. McGrath, supra note 8, at A2. 
a panacea for the ills of society, public schooling lias come to be seen as nothing more than a liarsh trade-off-one that promises a benefit to schoolchildren only after exacting a lieavy toll on their physical and psychological well-being.

Perliaps the prospect of judicially imposed liability will finally prompt schools to entertain serious consideration of school safety. Some efforts to combat the problem are already underway. North Carolina, for example, recently passed legislation making it a felony to bring a firearm to school. ${ }^{163}$ Moreover, three otler states-Florida, Louisiana, and Tennessee-have already adopted legislation authorizing schools to use metal detectors. ${ }^{164}$ Used by over fifty school systems across the nation, metal detectors have helped to curb the problem of weapons in schools. Strategies used in other countries also might prove instructive. Calgary, Canada, for instance, lias adapted a block watch program for schools under which students are encouraged to bring complaints of violence to the school's attention. ${ }^{165}$

The right to safe public scliooling comports with the established constitutional principle that the state must administer constitutionally even those services that it provides only voluntarily. ${ }^{166}$ The U.S. Supreme Court lias held consistently that the state is under no obhigation to provide free education for its citizens. ${ }^{167}$ Once the state elects to establish such a system, however, it must then administer that system in compliance witl the Constitution. ${ }^{168}$ Because children are compelled to attend public school, the Constitution entitles them to a safe education. The recent efforts of some states, described above, inspire cautious optimism. Any affirmative measure is a step in the right direction for public schools-the only possible direction if the riglit to an education is to mean more than an empty promise.

163. Act of July 24, 1993, 1993 N.C. Sess. Laws 558 (to be codified at N.C. GEN. STAT. \& 14-269.2).

164. David B. Rubin, Passing Through the "Schoolhouse Gate": Constitutional Implications of Preserving Student Safety, 154 N.J. LAW., July 1993, at 36, 39.

165. Lamb, supra note 4, at B3.

166. See Perry v. Sindermann, 408 U.S. 593, 597 (1972).

167. See, e.g., San Antonio Indep. Sch. Dist. v. Rodriguez, 411 U.S. 1, 35 (1973).

168. Goss v. Lopez, 419 U.S. 565 (1975). 